\title{
Pressuring Mrs Thomas to accept treatment: a case history
}

\author{
Brian Hurwitz Imperial College of Science, Technology and Medicine, London
}

\begin{abstract}
A general practitioner (GP) recounts events which unfolded after visiting a patient at home. She was found to be suffering from an entirely curable clinical condition which was worsening as a reult of refusal to accept effective medical treatment. The effects upon a grown-up son of the patient's refusal, and the increasing burden of care falling upon local district nursing services, were factors which influenced the GP's thinking and decision making.
\end{abstract}

(Fournal of Medical Ethics 1998;24:320-321)

Keywords: Informed voluntary refusal; testing refusal; competence; resources

Mrs Thomas (not her real name) was an elderly widow living with her bachelor son who had given up work in order to look after her. She had developed a huge basal cell carcinoma on her umbilicus, a slow-growing skin cancer that never invades distant sites and is almost always curable with radiotherapy treatment.

Mrs Thomas had initially been attended by one of the general practitioners in my practice and had refused hospital referral. But she had accepted a domiciliary visit by a consultant dermatologist who confirmed the diagnosis and explained the nature of the condition to her, offering daily outpatient treatment over a number of weeks, which Mrs Thomas refused. She had apparently always been terrified of hospitals, and preferred to live with the skin cancer which was not causing her too much difficulty at the time.

However, the cancer continued to enlarge across her abdomen. Though not painful, it began to ulcerate, becoming recurrently infected and requiring numerous dressings and washing. As well as the attentions of her son, whom as I have said, had already given up his job in order to look after her, she received daily district nursing help in an area with greatly overstretched community care resources.
I knew little about this patient until I was asked one day to visit her at home. I read the mediøal record and noted that my partner on numerds occasions had tried to persuade her to accept radiotherapy. On entering the house, I found

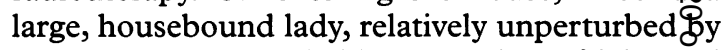
her condition, attended by an anxious, frightened man, her 50-year-old son, desperately trying to $\overrightarrow{8} 0$ his best for his mother.

I perceived in an instant the absurdity of फ्रe situation as it was developing: more and mơre community resources likely to be committed an indefinite period of time to the palliation off.an entirely curable condition which the patiens. apparently refusing to have treated appropraty and effectively. We were all being manipulated

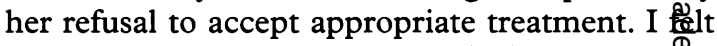
that I had a responsibility towards the commumty nursing staff and other patients in the locality $\overrightarrow{B 0}$ to allow scarce and valued resources to Be

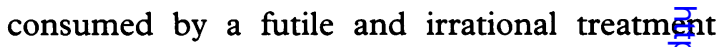
strategy. I therefore ordered her to attend hospital, and would hear nothing of her refusals. I wrôte immediately to the local radiotherapy unit fequesting urgent assessment, and asked that transport be arranged to outpatients. To my relgf, when the ambulance arrived she did not resist this course of action. Within six weeks, the uloer healed completely and her son retrieved a life for himself though he was unable, by then, to work.

\section{Case reflection}

Did I apply undue pressure upon Mrs Thomfsts? Though the proposed radiotherapy might catse tiredness and even some local skin reaction, 蛋e understood that there was a very good chancepof complete and painless cure. Her refusal seemedto result from an emotion frequently met withoin some patients, a child-like fear, not amountingto a phobia, of the institutional setting of proposed treatment. There was little suggestion that Motrs Thomas suffered from a delusion, or that she was impaired mentally. I had no grounds for doubting 
that her decision to stick with her slowly worsening condition had been a competent one, in the sense that she understood what was being proposed, its nature and purpose, its principal benefits, risks and alternatives, and the consequences of not receiving treatment. There seemed no reason to doubt that she could retain this information for long enough to make an effective decision, but the decision itself was strongly influenced by her fear of hospitals. It did not seem much influenced by considerations of local resource constraints. On the contrary, Mrs Thomas looked forward to the almost daily contact with district nurses.

My aim had been to act as a good doctor in the circumstances, in the best interests of Mrs Thomas, her son and the local community. Not being the GP who usually attended to this patient, I felt that my arrival on the scene offered the opportunity of a fresh approach to what had become a clinical impasse. I thought it was worth testing the strength of her resolve to refuse treatment. In my view, she had been waiting for someone to take control of the situation and was relieved that I had stood up to her. When confronted with an appointment for outpatients and a waiting ambulance, she had changed her mind.

\section{Acknowledgement}

I would like to thank my partner, Dr Berry Beaumont, for permission to report this case history.

Brian Hurwitz, MD, FRCP, MRCGP, is a General Practioner in Central London and a Senior Lecturer in General Practice in the Department of Primary Health Care and General Practice, Imperial College School of Science, Technology and Medicine, London.

\section{News and notes}

\section{Journal of Medical Ethics - http://www.jmedethics.com}

Visitors to the world wide web can now access the Fournal of Medical Ethics either through the BMJ Publishing Group's home page (http:// www.bmjpg.com) or directly by using its individual URL (http://www.jmedethics.com). There they will find the following:

- Current contents list for the journal

- Contents lists of previous issues

- Members of the editorial board

- Subscribers' information

- Instructions for authors

- Details of reprint services.
A hotlink gives access to:

- BMJ Publishing Group home page

- British Medical Association website

- Online books catalogue

- BMJ Publishing Group books.

The web site is at a preliminary stage and there are plans to develop it into a more sophisticated site. Suggestions from visitors about features they would like to see are welcomed. They can be left via the opening page of the BMJ Publishing Group site or, alternatively, via the journal page, through "about this site".

\section{News and notes}

\section{Gene Therapy: Ethical, Legal and Social Perspectives}

A conference entitled Gene Therapy: Ethical, Legal and Social Perspectives, organised by the Centre for Research Ethics, Uppsala, Sweden, in collaboration with the Deparment of Public Health and Caring Sciences, Uppsala and the Kennedy Institute of Ethics, Washington DC, USA, will be held at Uppsala, October 28-30, 1998.
For further information please contact: Uppsala Turist och Kongress “Gene Therapy", Fyris torg 8, S-753 10 Uppsala, Sweden. Tel: +46-18-27 48 07. Fax: +46-18-69 24 77. E-mail:kongress@utkab.se 